\title{
Floodplain reconstitution based on data collected via smartphones: a methodological approach to hydrological risk mapping
}

\section{Reconstituição de manchas de inundação baseada em dados coletados via smartphones: uma abordagem metodológica para o mapeamento de riscos hidrológicos}

\author{
${ }^{1}$ Universidade Federal de Pernambuco, Caruaru, PE, Brasil \\ ${ }^{2}$ Universidade Federal de Pernambuco, Recife, PE, Brasil
}

Ayane Aparecida da Silva Ribeiro ${ }^{1}$ (D), Gabriel Araujo de Oliveira ${ }^{2}$ (D), José Almir Cirilo ${ }^{1}$ (D), Fellipe Henrique Borba Alves² (D), Larissa Ferreira David Romão Batista² (D), Vitor Barbosa Melo (D)

E-mails: ayaneribeiro.50@gmail.com (AASR),goliveira.urb@gmail.com (GAO), almir.cirilo@gmail.com (JAC), fellipehba@hotmail.com (FHBA), larissafbatista@gmail.com (LFDRB),vitorbarbosamelo@hotmail.com (VBM)

Received: December 04, 2019 - Revised: June 10, 2020 - Accepted: June 13, 2020.

\begin{abstract}
The present study aimed to investigate the use of mobile applications on smartphones, specifically the Hidromapp application, as a technical support tool for flood data collection, as well as its use in flood mapping. To this end, information about a flood event of May 2017 was collected in the municipality of Jaqueira-Pernambuco, using smartphones and the Hidromapp application. Information was later used as input data for modeling and floodplain reconstitution. The study used geoprocessing techniques and a high-resolution Digital Terrain Model (Pernambuco Tridimensional - PE3D). For result evaluation, the reconstituted floodplain was compared with hydrodynamic modeling results using statistical indicators (RMSE and Critical Success Index - C). The app presented a good performance as a support tool for field collection of floodmark data. The applied method allowed a partially adequate estimation of the reconstituted event, in which the flooded area (extension) showed a high degree of similarity with the compared model, but with caveats for water surface elevations, where considerable discrepancies were detected in some points of the study area.
\end{abstract}

Keywords: Flood risk map; LiDAR; Hidromapp; Interpolation.

\section{RESUMO}

O presente estudo buscou investigar a utilização de aplicativos móveis em smartphones, especificamente o aplicativo Hidromapp, como ferramenta técnica de suporte para a coleta de marcas de cheia, incluindo também a aplicação dos dados coletados no mapeamento de áreas de inundação. Para tal, no município de Jaqueira-Pernambuco, foram coletadas em campo informações sobre a inundação ocorrida em maio de 2017, utilizando smartphones e o aplicativo Hiromapp. As informações foram posteriormente utilizadas como dados de entrada para a modelagem e reconstituição da mancha de inundação, por meio de técnicas de geoprocessamento e Modelo Digital de Terreno de alta resolução (Pernambuco Tridimensional - PE3D). Para a avaliação dos resultados, a mancha de inundação reconstituída foi comparada com resultados de modelagem hidrodinâmica, a partir de indicadores estatísticos (RMSE e Índice de Sucesso Crítico - C). Além disso, foram observados aspectos relacionados ao desempenho do aplicativo Hidromapp enquanto ferramenta de suporte para a coleta em campo de marcas de cheia. Como resultados, o aplicativo demonstrou bom desempenho para a coleta de dados em campo, e o método aplicado possibilitou uma estimativa parcialmente adequada do evento reconstituído, em que a área (extensão) da inundação apresentou alto grau de similaridade com o modelo comparado, porém com ressalvas para as profundidades da lâmina d'água, em que foram detectadas discrepâncias consideráveis em alguns pontos da área de estudo.

Palavras-chave: Mapa de risco de inundações; LiDAR; Hidromapp; Interpolação. 


\section{INTRODUCTION}

Floods are older than humankind is, since they are natural river phenomena and inherent part of any watercourse hydrological cycle. However, anthropogenic occupation along river basins can occur without proper planning, so that when occupying floodplains, it is common for the population to cope with disasters related to floods and flash floods (Tucci, 2007).

To reduce potential damage caused by extreme hydrological events, maps of flood-prone areas are essential tools at all stages of risk and disaster management, contributing to the planning and implementation of prevention, mitigation, preparation, and response actions. Shidawara (1999) and Kobiyama et al. (2006) mention that flood maps are even more indispensable in regions with no resources to implement forecasting and warning systems.

Although in Brazil, about 9,000 occurrences of hydrological disasters were recorded between 1995 and 2014 (Universidade Federal de Santa Catarina, 2016), many municipalities at risk do not have flood maps. The difficulties of cities usually occur due to the lack of professional staff, lack of instruments generally used in field surveys, or even the economic fragility, in which the scarcity of resources makes it impossible to hire specialized technical services.

For the elaboration of flood maps, traditionally hydraulic and hydrodynamic models have been used. These models allow the performance of numerical simulations in a computational environment, and consequently, floodplains delimitation referring to past events and simulation of hypothetical scenarios (Ribeiro Neto et al., 2015; Komi et al., 2017; Teng et al., 2017; Fadel et al., 2018). In parallel, methodologies for floodplain mapping based on GIS multicriteria analysis have also been presented in the literature, that encompasses physical-environmental aspects of the study area, such as altimetry, slope, distance from water bodies, soil type, and other related variables (Nardi et al., 2006; Magalhães et al., 2011; Nobre et al., 2011; Manfreda et al., 2014; Momo et al., 2016; Goerl et al., , 2017; Jafarzadegan \& Merwade, 2017).

Considering the intrinsic complexity in both methods, Kobiyama et al. (2006, p.33) point out floodplain reconstitution through field data as a simplified alternative, classified by the authors as empirical methodology. This method is based on mapping locations affected by flood events, including a water surface elevation survey, thus allowing floodplain delineation on an analogous cartographic base (printed), or digitally in a GIS environment.

Compared with hydraulic models and multicriteria analysis methods, it can be observed that the empirical methodology is simplified and can be easily replicated for the reconstitution of past events. Floodplain analysis made by geoprocessing techniques applied in Digital Elevation Models (DEM) has promoted advantages for regions that lack hydrological data, and for large hydrographic basins. This is motivated mainly by advances in high spatial resolution survey and by the availability of free topographic data with moderate quality (Nardi et al., 2006; Manfreda et al., 2014; Jafarzadegan \& Merwade, 2017).

However, it is still necessary to consider the availability of equipment for field surveys, such as Global Navigation Satellite System (GNSS) receivers, total stations, and other tools that allow georeferenced data collection, and a qualified technical staff for its operation. In this last aspect, smartphones improvement and popularization have enabled the development of mobile apps focused on technical and scientific functions. Applications for the most diverse purposes, developed specifically for technical ends, as can be seen in Lüthi Beat et al. (2014), Bartlett et al. (2015), Ho et al. (2016), Maeda et al. (2016), Hussain et al. (2017), Fernandes et al. (2018) and Harfouche et al. (2019).

Thus, with planimetric positional accuracy that can vary between 5 and 20 meters, smartphones stand as an alternative for performing georeferenced information field surveys (Oliveira et al., 2019). Besides presenting equivalent or even superior performance to GNSS navigation receivers, its operation does not require specific technical knowledge, and it is currently a tool available to $70 \%$ of the Brazilian population (Instituto Brasileiro de Geografia e Estatística, 2017).

Especially in the last decade, the development of locationbased mobile applications, focused on risk and disaster management, has been driven. Among these, collaborative initiatives stand out, covering concepts of crowdsourcing, collaborative mapping, voluntary geographical information and citizen science (Alfonso et al., 2010; Hirata et al., 2015; Horita et al., 2015; Le Coz et al., 2016; Assumpção et al., 2018; Seibert et al., 2019). As they are systems designed for the most diverse user profiles, regardless of their level of education, collaborative apps have driven the development of easy-to-use systems. With intuitive interfaces and free use, they contribute considerably to the collection of georeferenced information.

At the same time, these collaborative platforms can be constituted as technical tools for data collection, considering their use by professionals to collect information in the field. In many cases, small municipalities do not have equipment for mapping information, such as GNSS receivers, so that mobile applications can become efficient alternative tools, given their ease of use and the broad access of the population to smartphones.

In this context, the present study aims to explore the applicability of smartphones and a mobile app as a technical support tool for georeferenced flood data collection and to reconstitute floodplains from data collected via smartphones. As a case study, we sought to structure a methodological approach for mapping flood susceptible areas in the city of Jaqueira-PE, Brazil. Although a collaborative system (Hidromapp) is used for registration of flood marks, the study aims to evaluate the use of the application in an alternative way to GNSS navigation receivers for carrying out technical surveys, conducted by professionals, not necessarily involving population engagement.

\section{MATERIAL AND METHODS}

\section{Study area and reconstituted event.}

The conducted studies included the urban area of Jaqueira (approximately $1.5 \mathrm{~km}^{2}$ ), located in the Zona da Mata Sul region, Pernambuco State. The municipality is located in the Una river basin, whose city center is on the Pirangi River banks, one of its main tributaries (Figure 1 and Figure 2).

In the state of Pernambuco, the Una river basin is known for its long record of hydrological disasters, being currently monitored 


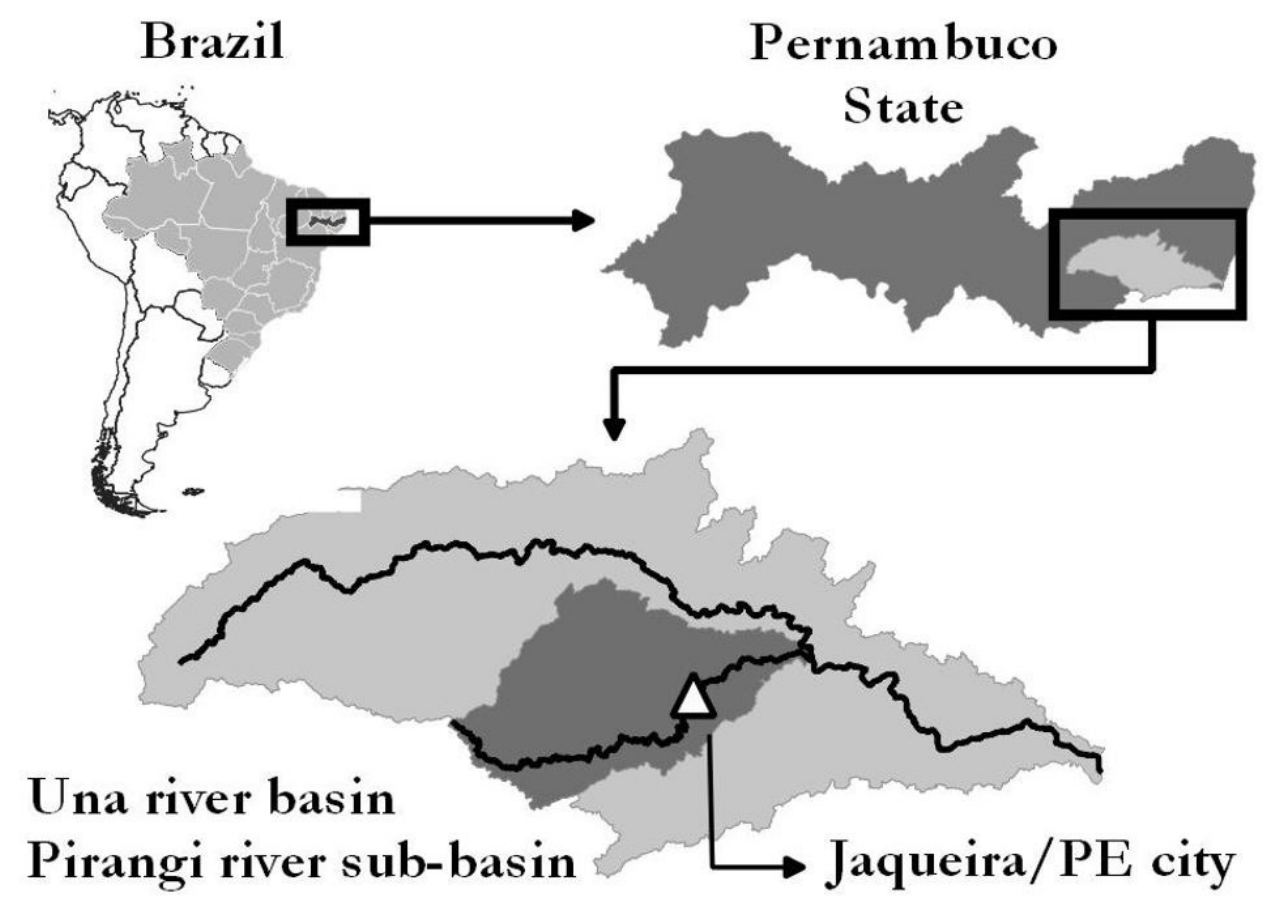

Figure 1. Jaqueira/PE location.

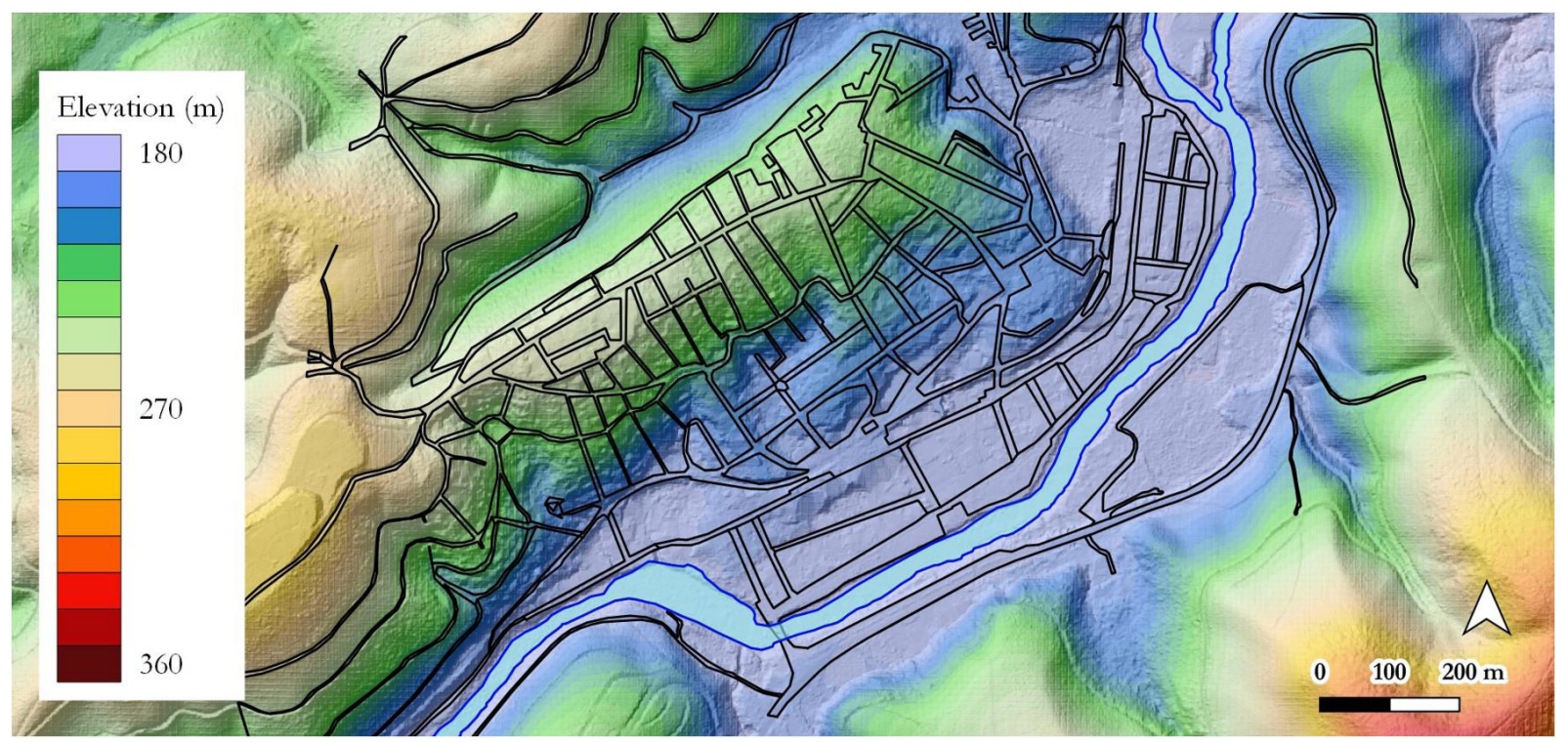

Figure 2. Study area.

by the Pernambuco Water and Climate Agency (APAC) and the National Center for Monitoring and Alerts for Natural Disasters (CEMADEN). Floods in this region cover the main river (Una), as well as its tributaries and bordering cities, such as the Pirangi river and city center of Jaqueira.

Since 2010, due to the most massive hydrological disaster in the region (Londe et al., 2005), several studies on the subject have been developed, as in Machado et al. (2012), Alves et al. (2013), Cavalcanti et al. (2013), Dantas et al. (2014), Monteiro et al. (2014), Londe et al. (2005), Ribeiro Neto et al. (2015), Amorim \& Silva (2016), Oliveira \& Silva (2016), Pereira et al. (2017), among others.

Thus, given the volume of scientific work carried out, it is possible to observe the magnitude of events in the region and the relevance of new contributions to hydrological risk management in the Una river basin.

In what regards to mapping flooded areas on an urban scale, there are no records of research developed for the municipality of Jaqueira. Thus, the selection of the study area in this work was intended to include small cities in the Una River Basin, which do not have studies related to floodplain surveys.

This study reconstituted a 2017 flood event, which affected 67 cities in the region, including Jaqueira (Figure 3). Between May 25 and 31, a $336 \mathrm{~mm}$ precipitation was recorded in Jaqueira, adding to the upstream rainfall, and leading to an increase in the Pirangi river flow and its overflow. The event affected 1200 residents in the municipality, which is equivalent to approximately $10 \%$ 

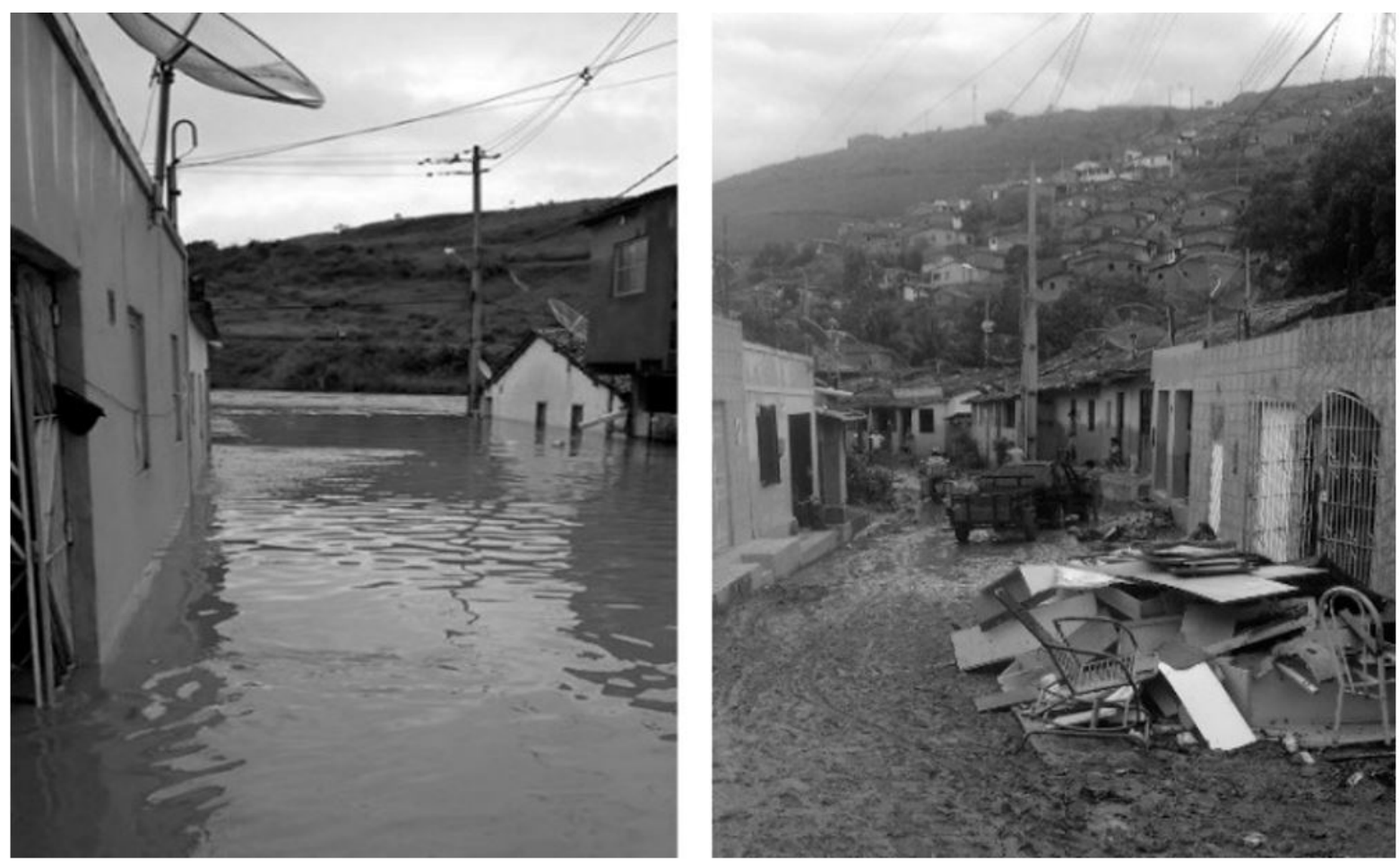

Figure 3. Impacts of the flood occurred in May 2017 in Jaqueira.

of its entire population. The effects are represented in Figure 3 (Comissão Externa das Chuvas em Alagoas e Pernambuco, 2017).

Although the 2010 disaster is considered as the most significant impact ever recorded in the Una basin, the 2017 event was selected for the case study as it is more recent, facilitating field data acquisition (flood marks in buildings, and dwellers interviews). Besides, the 2017 event also had a high impact.

\section{Data collection with smartphone}

For data collection with smartphones, we used the Hidromapp application (Figure 4). This latter is a mobile app in which users can collect and send information about floods that have already occurred. With this app, you can inform affected points, water surface elevation, year of occurrences, add photos, and complementary information in text message format (Oliveira et al., 2018).

In the app, collected information can be automatically georeferenced, through an integrated GPS, or by a function called "point on the map", which allows the collaborator to contribute from anywhere, not necessarily near the affected location. Hidromapp can be installed for free through the Google Play Store, which is compatible with Android devices.

Hidromapp automatically sends the collected data to the project database. If the device is offline, the information will remain saved in it until the internet connection is reestablished. After collection, the data can be viewed on the project website (http:/ / www.hidromapp.com.br) or by email request, in shapefile format.

As already mentioned, the empirical methodology for floodplain reconstitution is based on field survey and mapping of points, covering the affected area thoroughly (Kobiyama et al., 2006).
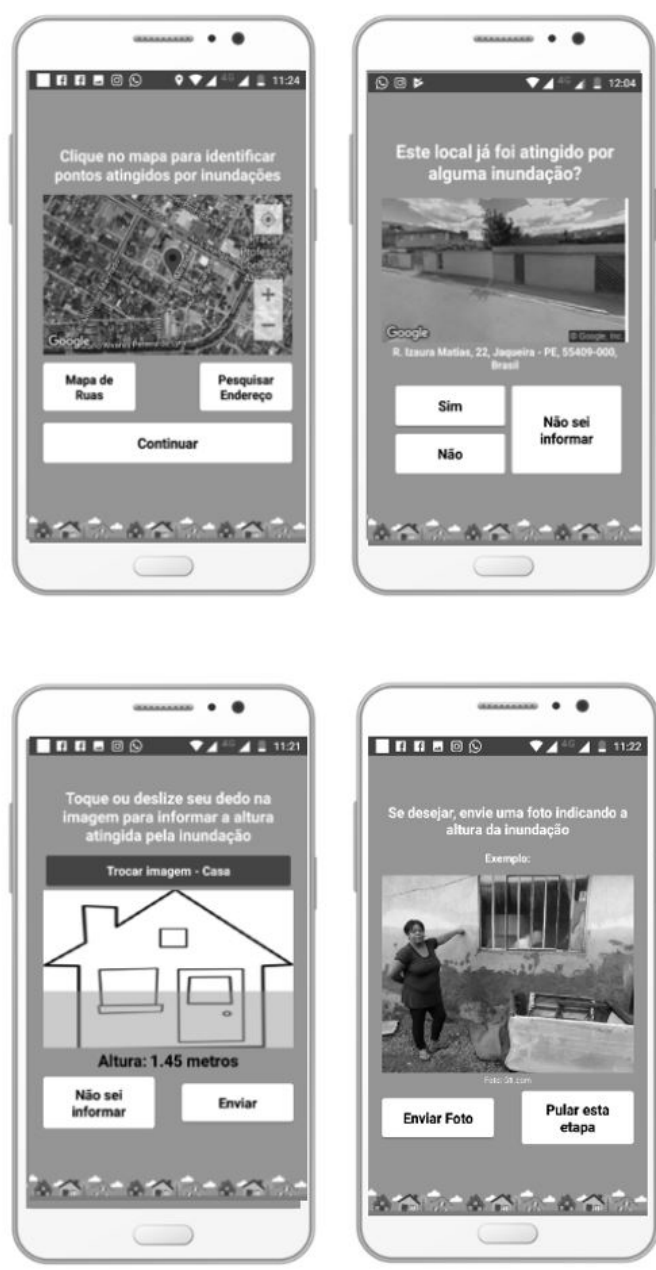

Figure 4. Hidromapp interface. 

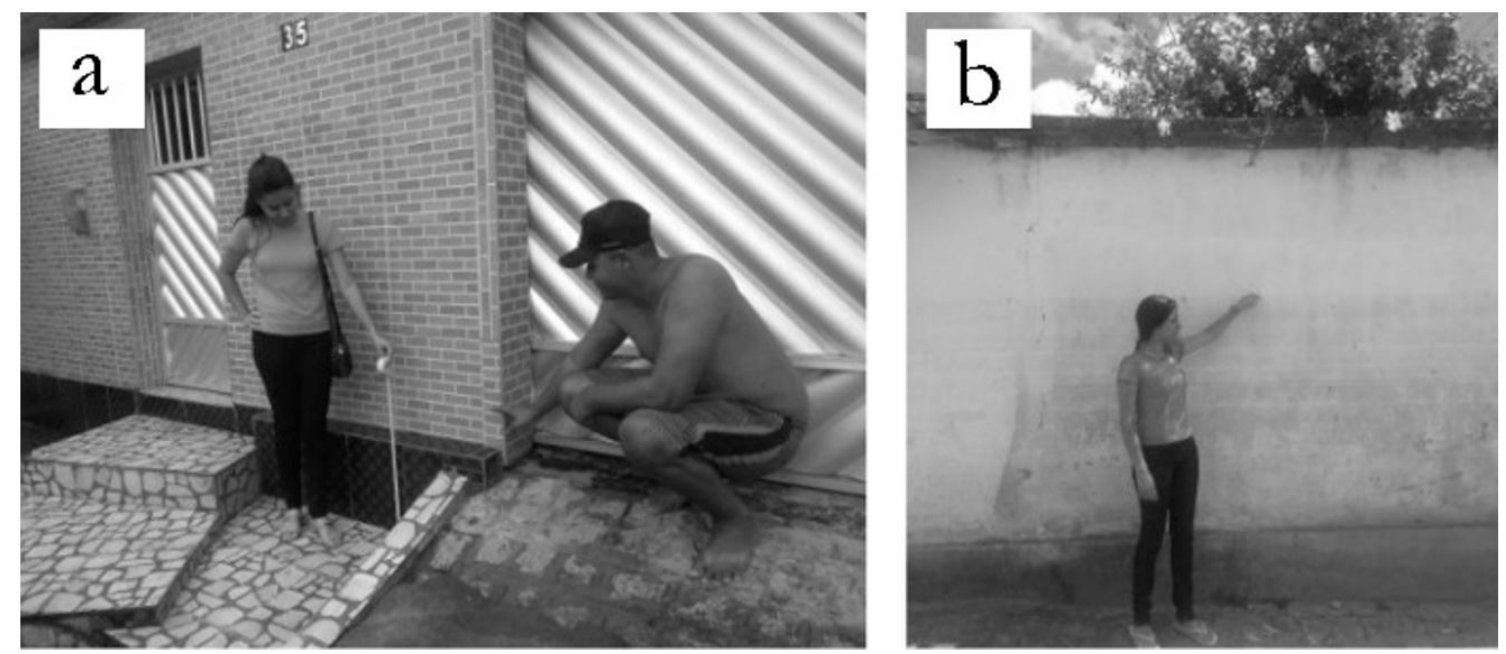

Figure 5. Data collection in the field. (a) Flood height measurement; b) Flood marks collection.

Thus, we sought to map locations in the limits (edge) of the 2017 affected area, as well as the places with the highest water depths.

In the field, water surface elevation was measured by measuring tape, for a more accurate survey. Data collection was performed by a group of researchers, mapping the main points affected by the flood that occurred in May 2017.

To register flood marks in the Hidromapp application, people living in the affected area were interviewed. It was only requested information about the depth reached by the flood in their respective homes. Thus, it was possible to measure the height observed at each point, with the help of a measuring tape (Figure 5a). In addition, flood marks that were still present in some buildings were also collected, as illustrated in Figure 5b.

It was also necessary to add points in inaccessible places to survey via GPS. Especially on river banks opposite to the area of urban occupation. In these cases, information was added to the Hidromapp application using the "Point on the map" function, based on values measured in the vicinity.

One hundred and thirty points were collected regarding the May 2017 flood event, 95 points gathered by the mobile phone GPS, and 35 points defined by the "Point on map" function. The obtained marks included directly affected locations and places on the edges of the flooded area (Figure 6).

Finally, considering that Hidromapp was conceived as a collaborative platform in which the population itself provides data, this paper intends to address its use as a technical support tool specifically. A device for engineers, civil defense and protection agents, and other professionals who work in risk and hydrological disaster management.

Still, one can consider the collaborative nature of this app, since all the collected data is available on the project website (http:/ / www. hidromapp.com.br). Other users in new tasks can access this data.

\section{Verification and adjustment of collected points}

After collection, verification of stored points was performed in a GIS environment (QGIS 3.8 software). The possibility of errors in the GNSS receiver positioning is considered. This step

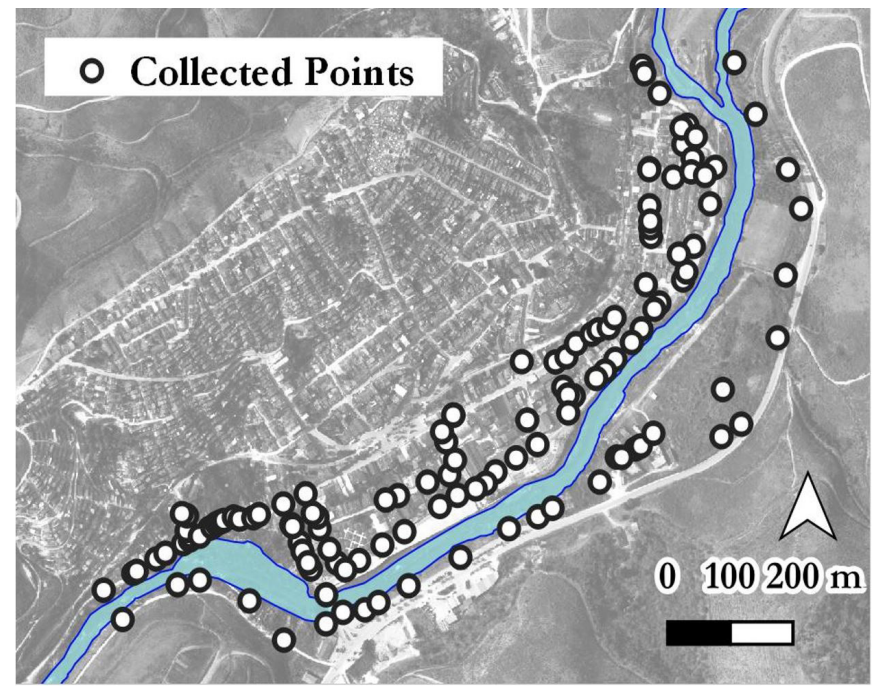

Figure 6. Flood marks collected with the Hidromapp app.

is necessary because errors in planimetric positioning can lead to considerable distortions in flood depth estimation, especially in steep slope places.

Thus, with the help of the Google Street View tool and photos from each survey point, it was possible to detect and adjust data location errors.

\section{Floodplain reconstitution}

Floodplain reconstitution was initially performed employing spatial interpolation techniques to the collected data, estimating flood depth throughout the study area in a distributed way (pixels). Then map algebra was used for flooded area delineation, which was based on the difference between interpolated flood depths and the Digital Terrain Model (DTM).

Similarly to experiments presented in Apel et al. (2009), Poser \& Dransch (2010), and Ribeiro Neto et al. (2015), field measured values (water surface elevation) were converted into flood depth, considering the terrain increment. As an altimetric support base, high-resolution DTM obtained by laser tillering through LiDAR technology was 
used, referring to the Pernambuco Tridimensional (PE3D) project. PE3D products have a 1-meter spatial resolution and an associated altimetric error of up to 25 centimeters (Cirilo et al., 2015).

All of the presented processes used the free software QGIS 3.8 so that replication of this methodology in other studies is possible at no cost. Thus, diminishing concerns in equipment acquisition for data collection and information processing.

After obtaining water surface elevations (flood depths + terrain elevation), the Multilevel B-Spline Interpolation was selected. The algorithm is available in QGIS, SAGA GIS module, and consists of a deterministic spatial estimator suitable for spatially random samples (Lee et al., 1997). Interpolations are performed from a sequence of bi-cubic B-Spline functions, iteratively generated, and based on optimization of an objective function (Lee et al., 1997).

Initially, other interpolators were tested, such as IDW and Triangulation. However, the multilevel B-Spline Interpolation showed better preliminary results, compared to the other interpolators tested. By visual interpretation of the interpolated data, in the testing phase, it was found that the Multilevel B-Spline enabled a reduction of extrapolated areas, without hydraulic connectivity with the flow channel.

In addition, the interpolator was selected because of its fast algorithm for interpolation and approximation of dispersed data. As this work does not aim to compare and evaluate the performance of different interpolators, details about other tested estimators are not discussed.

Multilevel B-Spline Interpolation is an estimator capable of extrapolation, so it was possible to estimate flood depths throughout the study area (Figure 7a). After that, the event reconstitution was obtained by map algebra, considering the difference between interpolated flood depths and DTM heights, as illustrated in Figure 7. Resulting values equal to or less than 0 (zero) were excluded (no data), leaving only the estimated interpolation floodplain (Figure 7c).

\section{Model performance analysis}

As a performance evaluation of the proposed method, the reconstituted floodplain was compared with a two-dimensional hydrodynamic simulation; similar to work performed by Manfreda et al. (2014) e Jafarzadegan \& Merwade (2017).

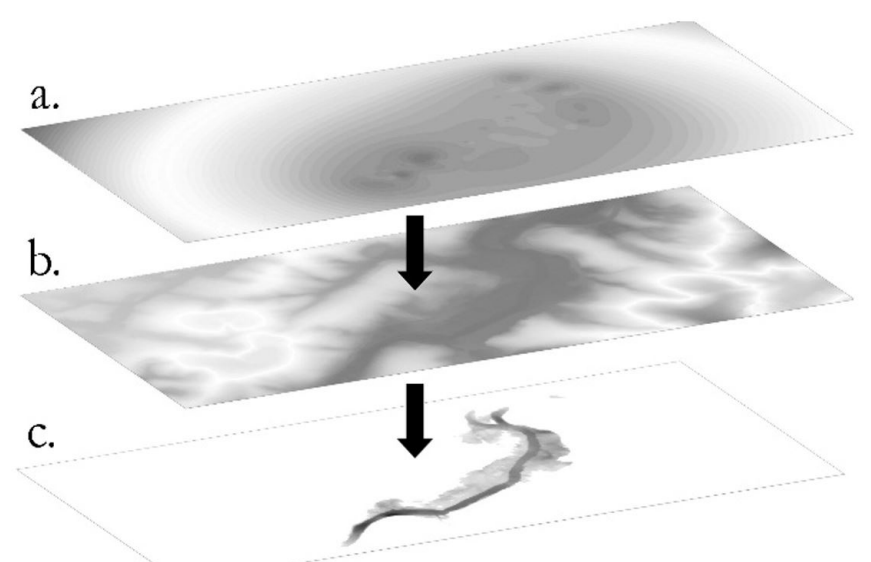

Figure 7. Map algebra for floodplain delimitation. (a) Interpolated water surface elevation (WSE); b) DTM LiDAR; c) Difference between interpolated WSE and DTM $(a-b)$.
The hydrodynamic model for reference simulation was developed with the HEC-RAS 5.0.6 program (United States Army Corps of Engineers, 2016). As a geometry, the same cut of the DTM was used, on which a computational net with a resolution of 10 meters was generated, and then refined to 5 meters around the river channel.

As an upstream boundary condition, the Flow Hydrograph option was used, for a hydrograph of the simulated event, adjusted from the nearest fluviometric station. Downstream the Normal Depth option was used, calculated from the slope of the section. The simulation used the computational interval of 1 minute and results every 5 minutes. After due calibration of the reference model from observations after the 2017 event, an average error of $0.32 \mathrm{~m}$ was identified between the simulated and observed depths (field data), these results being considered satisfactory for comparative analysis.

Thus, Root Mean Square Error (RMSE) was used to measure the degree of correspondence between interpolated $(\mathrm{HI})$ and simulated hydrodynamic modeling (HM) water surface elevations, Equation 1.

$$
\operatorname{RMSE}=\sqrt{\frac{\sum_{\mathrm{i}=1}^{\mathrm{n}}\left(\mathrm{HI}_{\mathrm{i}}-\mathrm{HM}_{\mathrm{i}}\right)^{2}}{\mathrm{n}}}
$$

where: $H I_{i}$ is water surface elevation estimated by interpolation; $H M_{i}$ is water surface elevation simulated in hydrodynamic model; $n$ is the number of pixels compared.

Critical Success Index (C) was used to evaluate interpolation performance, similarly to applications made by Manfreda et al. (2014), Wood et al. (2016), Jafarzadegan \& Merwade (2017), Wing et al. (2017), and Rollason et al. (2018). The index compares models based on the number of pixels classified as flooded (water depth greater than zero) and as not flooded (water depth equal to zero).

The $\mathrm{C}$ index is given by Equation 2, and its values may vary between 0 and 1 , indicating no similarity between the models or an optimal fit, respectively.

$$
\mathrm{C}=\frac{\mathrm{HI}_{1} \mathrm{HM}_{1}}{\mathrm{HI}_{1} \mathrm{HM}_{1}+\mathrm{HI}_{0} \mathrm{HM}_{1}+\mathrm{HI}_{1} \mathrm{HM}_{0}}
$$

where: $H I_{1}$ is the number of pixels estimated as flooded by the interpolation method; $H M_{1}$ is the number of pixels estimated as flooded by hydrodynamic modeling; $\mathrm{HI}_{0}$ is the number of pixels estimated as not flooded by the interpolation method; $H M_{0}$ is the number of pixels estimated as not flooded by hydrodynamic model.

Thus, based on the two applied indicators, we sought to evaluate the performance of the presented method (interpolation) when compared with hydrodynamic models, considering that modeling allows the best representation of floods. Finally, since the study focuses on an interpolation-based method, it is noteworthy that hydrodynamic modeling results were not explored in this work, being used only as a reference for comparative analysis.

\section{RESULTS AND DISCUSSION}

\section{Field data availability}

It was observed that information reported by the dwellers, presented logical consistency. As this was a recent event, a satisfactory level of detail was noted on the accuracy of data provided and on 
the number of trademarks in the properties. This scenario could not be evidenced for other events, such as the June 2010 flood.

In successive situations, residents of hazardous areas reported that such facts are impossible to be wholly forgotten, due to the watermarks and a trail of destruction left by the inundation. These still existing marks found in many houses contributed to data consistency, minimizing possible under or overestimation in dwellers observations.

On the other hand, there were difficulties to obtain information in uninhabited or not easily accessible areas, making it impossible to collect data either by interviews or flood mark identification. Thus, the importance of continuously register flood marks is noticed, a process that needs to be maintained whenever they occur, preventing information from being dissipated over time.

\section{Hidromapp performance}

Hidromapp has an interactive, didactical, and easy to understand interface. Data was collected from the user's positioning. That was possible due to integrated smartphone GPS, or the "point on map" function, which allows collaborations from anywhere, not necessarily near the affected area.

Regarding the GPS positioning accuracy, it was observed an average planimetric displacement of $5.46 \mathrm{~m}$ between the actual position of surveyed points and the estimates made by the app. This result was evaluated as a good performance (Oliveira et al., 2019). Among the 95 points collected through the smartphone
GPS, $51.6 \%$ of them had the planimetric error below $5 \mathrm{~m}$, and $34.8 \%$ had errors between 5 and 10 meters. About $7.4 \%$ of points presented error above $15 \mathrm{~m}$, with the maximum identified error of $21 \mathrm{~m}$.

Knowing that all the points had its positions corrected after collection, we highlight the need for verification and adjustment of points when surveying with GNSS receivers on smartphones. In this regard, the proposed method proved efficient, since the photos taken at each point allowed the position of information to be verified and adjusted using Google Street View.

In turn, to record flood heights, the app has normative dimensions that help users in estimating elevations, taking as reference windowsills, approximately $1.00 \mathrm{~m}$ from the ground, or door sizes, on average $2.10 \mathrm{~m}$ (Figure 8). Thus, it is possible to estimate the flood event range even if the user has no measuring instruments.

On the other hand, the method of recording water surface elevation through sliding over the screen (Figure 7) was less effective in field survey, since it was difficult to register exact measured heights, collected with measuring tape. Given the sensitivity of the smartphone's touch screen, it was challenging to report correct values to even one decimal place.

Thus, as a proposal, a new app function is suggested so the user can enter values by typing, alongside the already existing feature, which still is necessary for cases where there is no measurement equipment.

In terms of water surface elevation, users have to pay attention to references, because as observed, some houses are

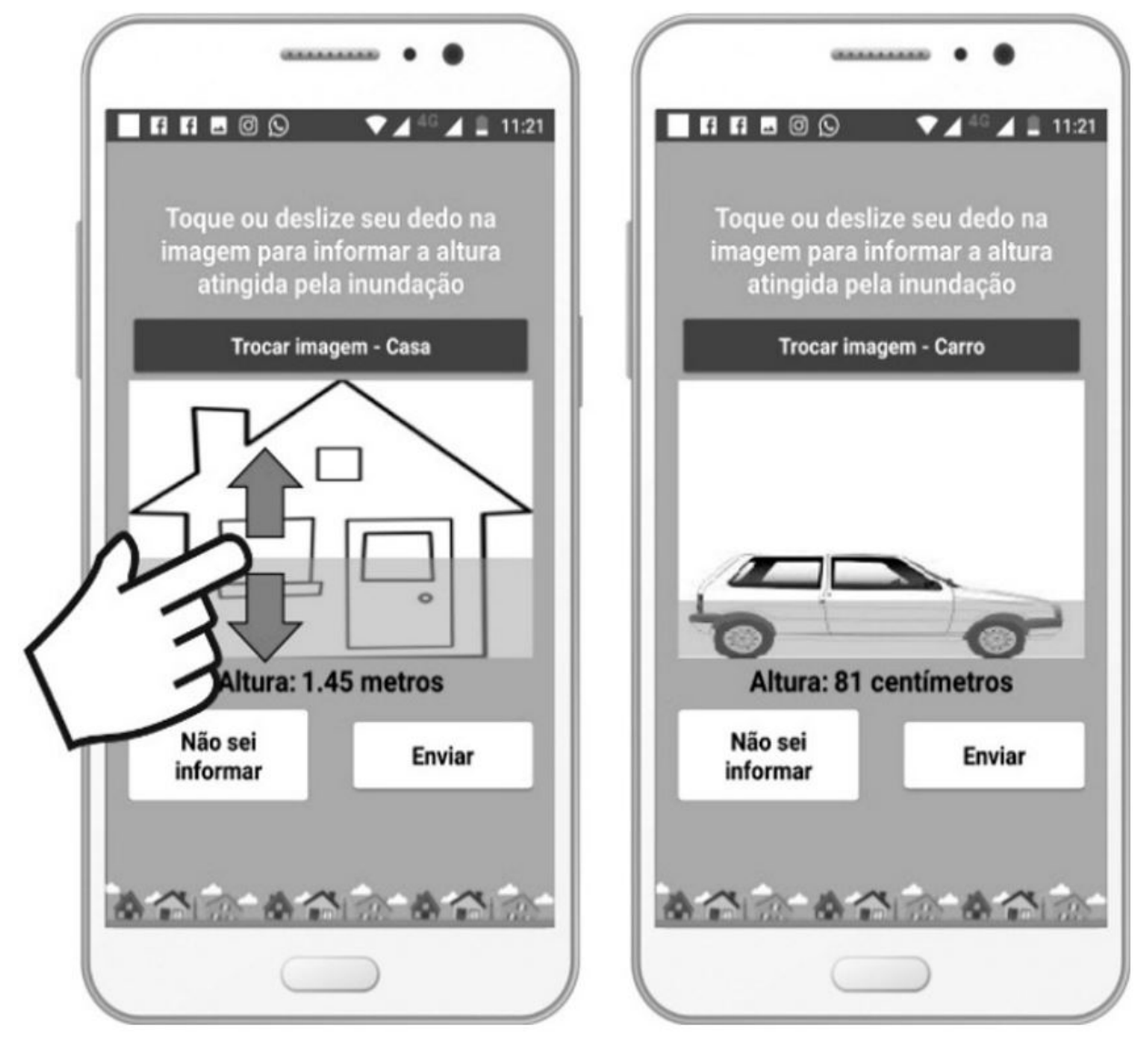

Figure 8. Flood depth record made through swipe up over the screen. 
built above the street level. In these situations, it was necessary to consider the same street level, which generally has more compliance with the DTM.

In specific situations, such as the ones mentioned above, the app served as a field book due to the "insert additional information" function. This latter allowed such specificities to be recorded in each of the collected points as texts. The same happened to photographic records, which served not only to illustrate the water surface elevation but also to ascertain the information after collection and processing.

In general, the app made it possible to record as much information as was observed in the field without the need for ancillary equipment. Although the app has been developed a priori for the population daily use, its interface and operation proved to be suitable for technical applications as well. It could be adopted by professional teams working with hydrological risk management, regardless of their education or degree, given the importance of maintaining floodmark records, as mentioned earlier.

Although information can be viewed on the project website immediately, it was necessary to request data in shapefile format via email to continue the experiments. Thus, the platform still lacks some resources to download data after collection.

\section{Reconstituted floodplain and model performance}

The methodology used for floodplain delineation through map algebra and interpolation allowed the May 2017 event reconstitution, in Jaqueira. From a qualitative aspect, it is possible to observe the most affected regions as well as the destructive inundation power, Figure 9a.

Located on the Pirangi river left bank, the most damaged region is densely inhabited and consequently has a high vulnerability index (Figure 9a). Thus, it was possible to observe coherence among population reports transcribed to flood mark points. The applied method allowed identification of flooding in specific locations recognized by the residents as risky places, such as Das Viúvas Street and Miguel Pellegrino Street, the municipal nursery, two schools, the public gym, and patio of events.

For the region where the PE-126 highway is located, the model responded satisfactorily, not extrapolating the floodplain to this area, in agreement with the real event. Likewise, the commercial area was not included in the reconstituted floodplain, which is also verified by the event. Thus, it was observed that the applied model could identify affected areas and locations beyond flood reach.

In performance evaluation by statistical indicators, the resulting C index was 0.91 , thus demonstrating a high degree of similarity between both floodplains, the reconstituted by interpolation and the hydrodynamic modeled, used as a reference. The differences between flooded areas were considered satisfactory with a value of only $3.1 \%, 0.31 \mathrm{~km}^{2}$ in the interpolated model, and $0.32 \mathrm{~km}^{2}$ in the hydrodynamic model (Figure 9). Additionally, it is observed that in areas where estimates did not match, water surface elevation was inferior to $0.15 \mathrm{~m}$, still satisfactory in terms of risk analysis.

For water surface elevation, the calculated RMSE registered $0.64 \mathrm{~m}$, indicating significant differences concerning the hydrodynamic model. This result is equivalent to related studies by Apel et al.
(2009), Poser \& Dransch (2010) and Scorzini et al. (2018), with the obtained RMSE of $0.87,0.76 \mathrm{~m}$ and $0.50 \mathrm{~m}$ respectively.

In $57 \%$ of the points interpolated, the differences found in the water depth values were up to $0.5 \mathrm{~m}$, representing good similarity with the results of hydrodynamic modeling (Figure 9). Similarly, $90 \%$ of the points presented a difference of less than $1 \mathrm{~m}$ (Figure 9). Regarding hydrodynamic model precision, measured at $0.32 \mathrm{~m}$, it was found that approximately $30 \%$ of the values estimated by interpolation presented differences of up to this acceptable margin of error.

Finally, the coefficient of determination $\mathrm{R}^{2}$ was 0.84 . It satisfactorily represented the degree of correspondence between the floodplain reconstituted by interpolation and the results of the hydrodynamic model (Table 1).

As discussed in Apel et al. (2009), Poser \& Dransch (2010) and Pinheiro et al. (2019), among others, it is also necessary to consider in this work that hydrodynamic models have their inner evaluation errors. In some cases, values simulated by alternative methods may present greater correspondence with the event.

However, it is noteworthy that high discrepancies were detected at some points, around three meters. This represents errors in the applied model, regardless of the uncertainty degree in the compared hydrodynamic model (Figures 10 and Figure 11).

It was observed that the primary error source in the applied model was concentrated in points of inaccessible areas, where information was collected remotely, on the right river bank. In Figures 11, 12 and Table 2 it is possible to observe the behavior of estimated water surface elevation in these points, specifically in the sections " 5 - 6", "13 - 14", "19-20", "21 - 22", and "23 - 24".

In these situations, the need for greater precision becomes evident for points positioned in areas with a steep slope, where small planimetric displacements may compromise the estimated flood depth. In this regard, an alternative can be to adjust the position of points so that flood depths are equivalent to values

Table 1. Interpolated model performance.

\begin{tabular}{cc}
\hline Indicator & Result \\
\hline C Index & 0.91 \\
RMSE & $0.64 \mathrm{~m}$ \\
$\mathrm{R}^{2}$ & 0.84 \\
\hline
\end{tabular}

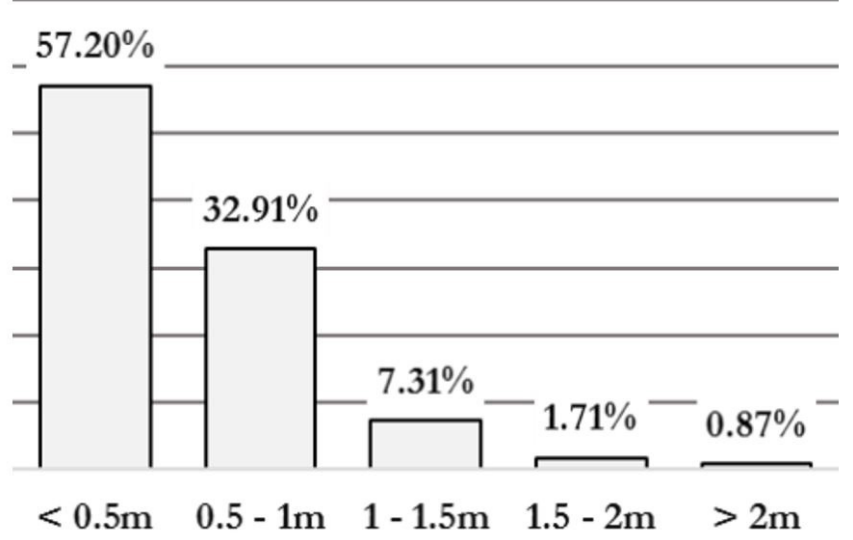

Figure 9. Discrepancies calculated between the interpolated model and the hydrodynamic model - Frequency distribution. 
a) Flood Depth - Interpolated Model

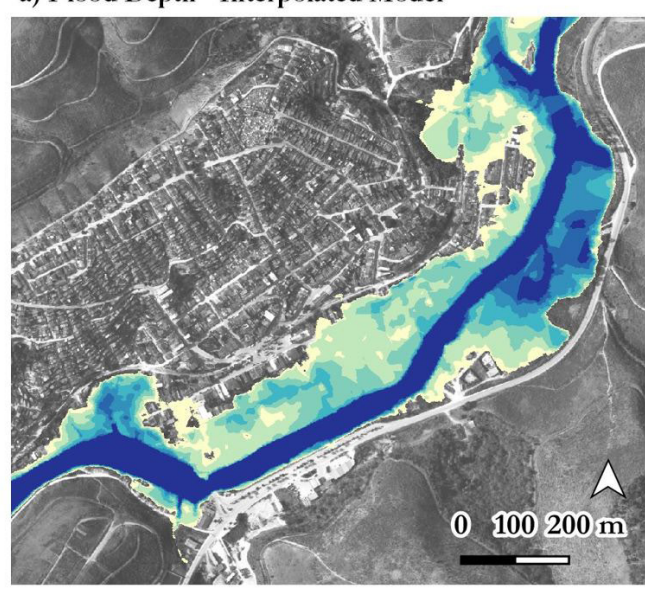

b) Flood Depth - Hydrodynamic Model

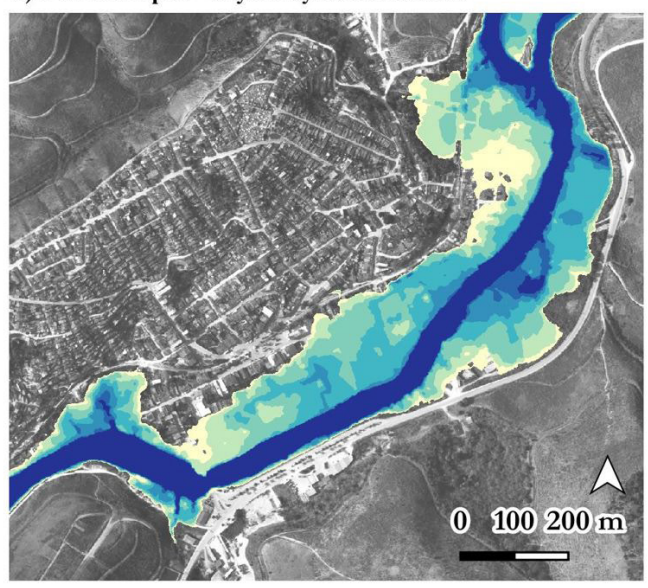

\section{Flood Depth (meters)}

$0.01-0.5$
$0.5-1$

$1-1.5$

$1.5-2$

$2-2.5$

$2.5-3$

$>3$

Figure 10. Floodplain reconstituted by interpolation (a) and by hydrodynamic model (b).

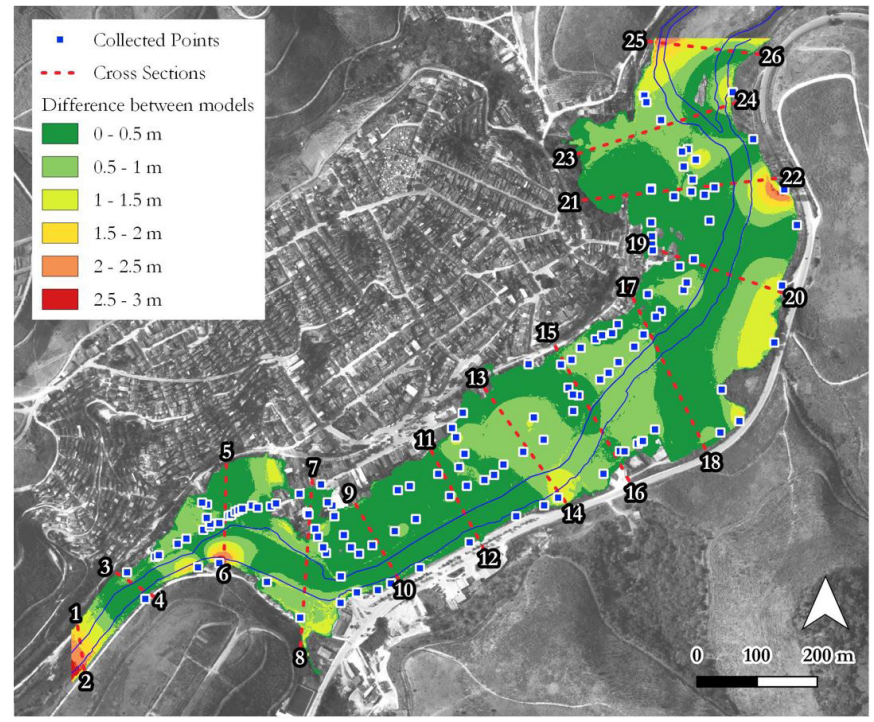

Figure 11. Flood depth differences (Interpolated - Hydrodynamic Model).

$\underline{\text { Table 2. Differences between estimated water depth in cross-sections }}$

\begin{tabular}{cc}
\hline Cross-section & $\begin{array}{c}\text { Average difference } \\
\text { between models } \\
\text { (meters) }\end{array}$ \\
\hline $1-2$ & 1.29 \\
$3-4$ & 0.23 \\
$5-6$ & 0.51 \\
$7-8$ & 0.32 \\
$9-10$ & 0.14 \\
$11-12$ & 0.16 \\
$13-14$ & 0.74 \\
$15-16$ & 0.27 \\
$17-18$ & 0.29 \\
$19-20$ & 0.33 \\
$21-22$ & 0.35 \\
$23-24$ & 0.45 \\
$25-26$ & 0.83 \\
\hline
\end{tabular}

situated on opposite banks. Thus, water surface elevation will have a smooth flat profile in cross-sections, similar to the hydrodynamic model, and errors will be then minimized. In addition, mechanisms for the floodplain refinement can also be applied, as presented in Samela et al. (2018) and Nardi et al. (2006), in which the authors use geoprocessing techniques and geomorphological data to remove distortions in the estimate of the flooded area.

Still, compared to the hydrodynamic model, the applied method presented significant differences for unsampled areas, where no points were collected, and the values were estimated by extrapolation, as can be seen in sections " 1 - 2 " and " 25 - 26" (Table 2 and Figures 11 and 12). In these cases, in future works, the extension of results may be limited, discarding areas in which the values were estimated by extrapolation (with no observed values).

Errors were detected in model cross-sections, and in the longitudinal profile, drawn on the river axis (Figure 13). Throughout the longitudinal profile, an average difference of $0.49 \mathrm{~m}$ was identified between the interpolation estimated water depth and the hydrodynamic model. At some points, the calculated discrepancy was $2.5 \mathrm{~m}$ (Figure 13). It was observed that the significant differences detected in the longitudinal profile were also caused by errors of data collected in inaccessible areas.

In sum, these results reinforce that the proposed model performed well in estimating the flooded area (edges and extension), but also resulted in considerable discrepancies in flood depth estimation. Although the proposed method consists of an empirical model, disregarding the physical and conceptual principles of the simulated phenomenon, in both situations (cross-sections and longitudinal profile), the interpolated model was not able to reproduce flooding behavior in specific locations.

Finally, the Multilevel B-Spline Interpolation interpolator performed well, considering that errors are concentrated in places where the collected information presented inconsistencies. In the other areas, where data were consistent, the event estimated by interpolation showed similarities with the compared hydrodynamic model. 


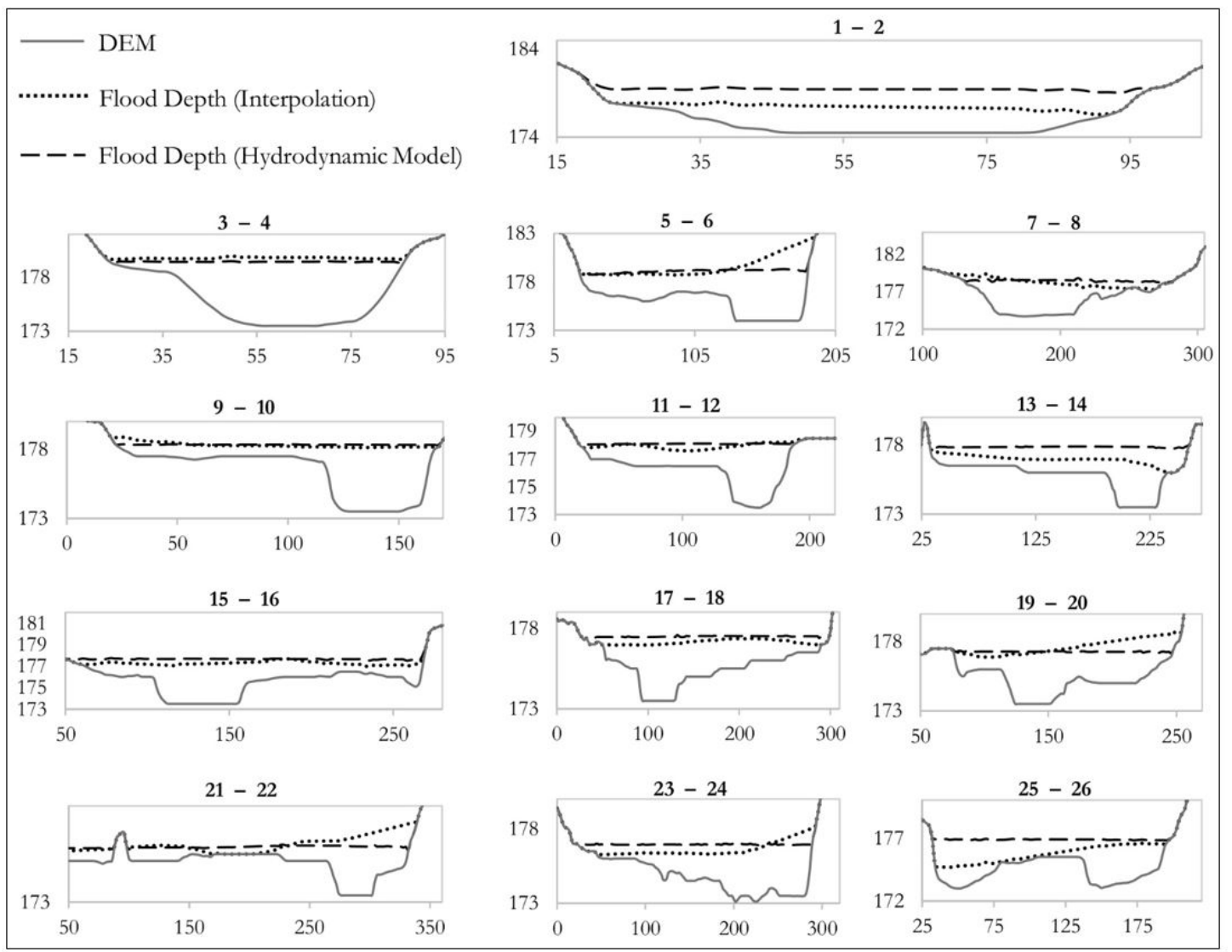

Figure 12. Model cross-sections performance.

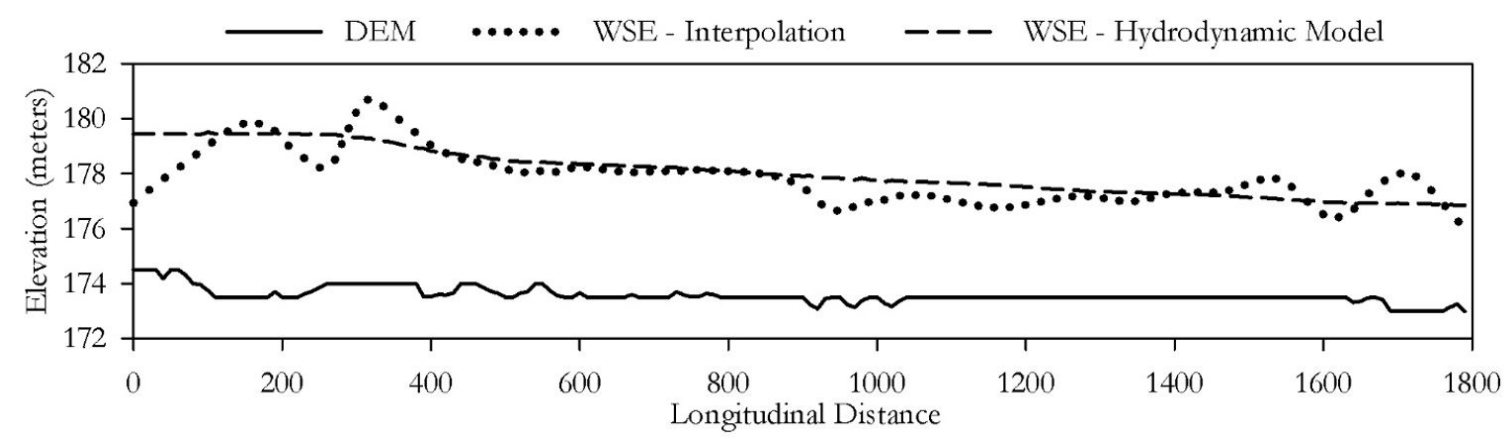

Figure 13. Longitudinal profile - Water Surface Elevation (WSE) along Pirangi river.

\section{CONCLUSIONS}

The present study sought to map the areas subject to flooding in the municipality of Jaqueira through field data survey, carried out with the Hidromapp application, to evaluate its applicability for technical purposes. In addition, the use of algorithms based on interpolations for the reconstitution of flood spots from flood marks was investigated.

Compared to the hydrodynamic model, the results of the applied methodology were partially satisfactory, presenting a good performance in estimating flooded areas (extension), but resulting in some points with considerable discrepancies for estimated water surface elevation. In this regard, the indicators used to evaluate results were adequate and allowed quantitative and systematic analysis of the proposed model. In addition, cross-section and longitudinal profile analysis showcased model inconsistencies, which were not explicit in the applied indicators.

It was observed that the main source of error in the experiments concentrated in points collected in inaccessible places and points not sampled, especially in uninhabited areas, which resulted in distortions in the interpolated model. As for recommendations in this regard, there is the adjustment of water depth values, still in the pre-processing, and other mechanisms for the refinement of the floodplain can also be explored.

In addition, the importance of data collection in the immediate aftermath of the flooding event was evidenced. It enabled the registration of flood marks in the entire flooded area, contributing to better results in interpolation. About the approach explored, it is expected that the methodological procedures presented here can contribute to professionals from Civil Defense 
and Protection System to act in flood marks registration since the reliability of the information is fundamental to good results. On the other hand, data reported by the population are more subject to misunderstandings, especially when collected long after the event occurred.

Regarding the database, it is also concluded that the use of a high-resolution digital terrain model (PE3D) was fundamental. In this regard, further work can explore the performance of the proposed methodology using lower resolution DEMs such as SRTM, MERIT and NASADEM, contributing to the application of the methodology presented on a large scale or in municipalities that do not have high spatial resolution DEMs.

The selected algorithm for data interpolation (Multilevel B-Spline Interpolation) performed well. Errors were concentrated in places where gathered information indicated inconsistencies, but in other areas, the interpolator obtained satisfactory results. On the other hand, because it is a deterministic interpolator and considers the behavior of the isotropically modeled phenomenon (same intensity in all directions), the results can be optimized by using a probabilistic and anisotropic interpolator, such as anisotropic kriging.

Hidromapp, an application used for data collection in the field, is a light, easy to use, low energy, and mobile data demanding system. Thus its use is recommended for field collection of flood marks, even in technical applications. However, since the platform does not have tools for users to download data, it was necessary to establish direct communication with the project creators to request and gain access to the data collected in this experiment.

This study intends to allow new possibilities in the engineering field for this app, both for its low cost and ease of handling. Thus, encouraging its insertion as a technical support tool for flood marks collection, as well as the use of collected information for flood mapping.

The methodological approach presented aims primarily to support small municipalities with limited economic resources available for flood mapping, which is considered one of the main tools in hydrological risk management. In addition, the study contributes to the calibration of hydraulic prediction models, based on the reconstruction of past events. The process helps to fill in the information gaps, adjusting the models in past events, and thus adapting them to simulate future situations.

\section{ACKNOWLEDGEMENTS}

The authors acknowledge with gratitude the support of CNPq, CAPES, the Science and Technology Support Foundation of the Pernambuco state (FACEPE), as well as the several students who contributed to the development of the work. The authors also acknowledge the reviewers and editors of RBRH for the contributions that have enhanced this work.

\section{REFERENCES}

Alfonso, L., Lobbrecht, A., \& Price, R. (2010). Using mobile phones to validate models of extreme events. In 9th International Conference on Hydroinformatics, Tianjin: HIC.
Alves, K. M. A. S., Cavalcanti, L., \& Nóbrega, R. S. (2013). Eventos extremos e risco de inundação: uma análise do comportamento evolutivo dos distúrbios ondulatórios de leste em junho de 2010 sobre a bacia do Rio Una Pernambuco. Geotextos, 9(2), 173-189. http://dx.doi.org/10.9771/1984-5537geo.v9i2.6628.

Amorim, G., \& Silva, S. (2016). Gerenciamento de risco de enchente: o caso Palmares. Revista de Engenharia e Pesquisa Aplicada, 2(1), 268277. http://dx.doi.org/10.25286/repa.v2i1.345.

Apel, H., Aronica, G., Kreibich, H., \& Thieken, A. (2009). Flood risk analyses - how detailed do we need to be? Natural Hazards, 49(1), 79-98. http://dx.doi.org/10.1007/s11069-008-9277-8.

Assumpção, T. H., Popescu, I., Jonoski, A., \& Solomatine, D. P. (2018). Citizen Observations Contributing to Flood Modelling: opportunities and Challenges. Hydrology and Earth System Sciences, 22(2), 1473-1489. http://dx.doi.org/10.5194/hess-22-1473-2018.

Bartlett, A. C., Andales, A. A., Arabi, M., \& Bauder, T. A. (2015). A smartphone app to extend use of a cloud-based irrigation scheduling. Tool Computers and Electronics in Agriculture, 111, 127-130. http://dx.doi.org/10.1016/j.compag.2014.12.021.

Cavalcanti, R. C., Tavares Junior, J. R., \& Candeias, A. L. B. (2013). Simulação de mapeamento de riscos de inundações usando dados LiDAR: estudo de caso da bacia do Rio Una - PE. Revista Brasileira de Cartografia, 65(4), 703-716.

Comissão Externa das Chuvas em Alagoas e Pernambuco CEXCHUV. (2017). Relatório final da Comissão Externa das Chuvas em Alagoas e Pernambuco. Recife, PE: Comissão Externa das Chuvas em Alagoas e Pernambuco.

Cirilo, J. A., Alves, F. H. B., Silva, B. M. S., \& Campos, P. H. A. L. (2015, Novembro 22-27). Pernambuco Tridimensional: Base de dados espaciais para planejamento urbano e gestão territorial. In: 12th Simpósio de Hidráulica e Recursos Hidricos dos Países de Expressão Portuguesa, Brasilia: ABRH.

Dantas, C. E. O., Cirilo, J. A., Ribeiro Neto, A., \& Silva, E. R. (2014). Caracterização da formação de cheias na bacia do rio Una em Pernambuco: análise estatística regional. Revista Brasileira de Recursos Hidricos, 19(4), 239-248. http://dx.doi.org/10.21168/ rbrh.v19n4.p239-248.

Fadel, A. W., Marques, G. F., \& Goldenfum, J. A. (2018). Mapeamento do risco de prejuízo como medida de gestão e adaptação às inundações. Geociências, 37(1), 121-136. http://dx.doi.org/10.5016/ geociencias.v37i1.11822.

Fernandes, P. G. P. S., Carvalho, P. H. F. C., Nobre Júnior, E. F., \& Oliveira, F. H. L. (2018, Novembro 4-7). Avaliação das condições de superfície de pavimentos rodoviários por meio do VSA e do IRI obtido por aplicativo para smartphones. In: 32. Congresso de Pesquisa e Ensino em Transportes. Gramado: ANPET.

Goerl, R. F., Michel, G. P., \& Kobiyama, M. (2017). Mapeamento de áreas susceptíveis a inundação com o modelo HAND e análise 
do seu desempenho em diferentes resoluções espaciais. Revista Brasileira de Cartografia, 69(1), 61-69.

Harfouche, T. B., Corte, A. P. D., Ruza, M., \& Behling, A. Uso de aplicativos em smartphone para medições de árvores. BIOFIX Scientific Journal, 4(1), 7-15. 2019.

Hirata, E., Giannotti, M. A., Larocca, A. P. C., \& Quintanilha, J. A. (2015). Flooding and inundation collaborative mapping - use of the Crowdmap/Ushahidi platform in the city of Sao Paulo, Brazil. Journal of Flood Risk Management, 11(S1), xx-xx.

Ho, C., Lai, C., \& Almonnieay, A. (2016 June 20-24). Using Geographic Information Systems and Smartphone-Based Vibration Data to Support Decision Making on Pavement Rehabilitation. In: J. P. Carvalho, M.-J. Lesot, U. Kaymak, S. Vieira, B. Bouchon-Meunier, R. R. Yager. 16th International Conference on Information Processing and Management of Uncertainty in Knowledge-Based Systems. Eindhoven: Springer. http://dx.doi.org/10.1007/978-3-319-40596-4_40.

Horita, F. E., De Albuquerque, J. P., Degrossi, L. C., Mendiondo, E. M., \& Ueyama, J. (2015). Development of a spatial decision support system for flood risk management in Brazil that combines volunteered geographic information with wireless sensor networks. Computers \& Geosciences, 80, 84-94.

Hussain, I., Das, A., Ahamad, K. U., \& Nath, P. (2017). Water salinity detection using a smartphone. Sensors and Actuators. B, Chemical, 239, 1042-1050. http://dx.doi.org/10.1016/j.snb.2016.08.102.

Instituto Brasileiro de Geografia e Estatística - IBGE. Pesquisa Nacional de Amostra por Domicilio Contínua (PNAD 2017): acesso à internet e à televisão e posse de telefone móvel celular para uso pessoal: 2017. Rio de Janeiro, RJ: IBGE, 2017.

Jafarzadegan, K., \& Merwade, V. (2017). A DEM-based approach for large-scale floodplain mapping in ungauged watersheds. Journal of Hydrology, 550, 650-662.

Kobiyama, M., Mendonça, M., Moreno, D. A., Marcelino, I. P. V. O., Marcelino, E. V., Gonçalves, E. F., Brazetti, L. L. P., Goerl, R. F., Molleri, G., \& Rudorff, F. (2006). Prevenção de desastres naturais: conceitos básicos. Curitiba, PR: Organic Trading.

Komi, K., Neal, J., Triggc, M. A., \& Diekkrüger, B. (2017). Modelling of flood hazard extent in data sparse areas: a case study of the Oti River basin, West Africa. Journal of Hydrology: Regional Studies, 10, 122-132.

Le Coz, J., Patalano, A., Collins, D. B., Guillén, N. F., García, C. M., Smart, G. M., Bind, J., Chiaverini, A., Boursicaud, R. L., Dramais, G., \& Braud, I. (2016). Crowdsourced data for flood hydrology: Feedback from recent citizen science projects in Argentina, France and New Zealand. Journal of Hydrology, 541(part B), 766-777.

Lee, S., Wolberg, G., \& Shin, S. Y. (1997). Scattered Data Interpolation with Multilevel B-Splines. IEEE Transactions on
Visualization and Computer Graphics, 3(3), 228-244. http://dx.doi. org/10.1109/2945.620490.

Londe, L. R., Marchezini, V., Conceição, R. S., Bortoletto, K. C., Silva, A. E. P., Santos, E. V., \& Reani, R. T. (2005). Impactos de desastres socioambientais em saúde pública: estudos dos casos dos Estados de Santa Catarina em 2008 e Pernambuco em 2010. Revista Brasileira de Estudos de Populacao, 32(3), 537-562. http:// dx.doi.org/10.1590/S0102-3098201500000031.

Lüthi Beat, L., Thomas Philippe, T., \& Peña-Haro, S. (2014). Mobile device app for small open-channel flow Measurement. In: 7 th International Congress on Environmental Modelling and Software. San Diego: iEMS.

Machado, C. C. C., Nóbrega, R. S., Oliveira, T. H., \& Alves, K. M. A. S. (2012). Distúrbio Ondulatório de Leste como condicionante a eventos extremos de precipitação em Pernambuco. Revista Brasileira de Climatologia, 11, 146-188. http://dx.doi.org/10.5380/ abclima.v11i0.28699.

Maeda, H., Sekimoto, Y., \& Seto, T. (2016 October 31). Lightweight Road Manager: Smartphone-based automatic determination of road damage status by deep neural network. In: ACM Sigspatial 5 th International Workshop on Mobile Geographic Information Systems (pp. 37-45) Burlingame: ACM.

Magalhães, I. A. L., Thiago, C. R. L., Agrizzi, D. V., \& Santos, A. R. (2011). Uso de geotecnologias para mapeamento de áreas de risco de inundação em Guaçuí, ES: uma análise comparativa entre dois métodos. Cadernos de Geociências, 8(2), 63-70.

Manfreda, S., Nardi, F., Samela, C., Grimaldi, S., Taramasso, A. N., Roth, G., \& Sole, A. (2014). Investigation on the use of geomorphic approaches for the delineation of flood prone areas. Journal of Hydrology (Amsterdam), 517, 863-876. http://dx.doi.org/10.1016/j. jhydrol.2014.06.009.

Momo, R. M., Pinheiro, A., Severo, D. L., Cuartas, L. A., \& Nobre, A. D. (2016). Desempenho do modelo HAND no mapeamento de áreas suscetíveis à inundação usando dados de alta resolução espacial. Revista Brasileira de Recursos Hídricos, 21(1), 200-208. http:/ / dx.doi.org/10.21168/rbrh.v21n1.p200-208.

Monteiro, K. A., Correa, A. C. B., Melo, R. F. T., Meira, D. A., Nóbrega, R. S., \& Girao, O. (2014). Parâmetros morfométricos aplicados à bacia do Rio Una (Pernambuco-Brasil) para identificar susceptibilidade a enchentes. Revista Geográfica de América Central, 1(52), 163-177.

Nardi, F., Vivoni, E. R., \& Grimaldi, S. (2006). Investigating a floodplain scaling relation using a hydrogeomorphic delineation method. Water Resources Research, 42(9), 1-15. http://dx.doi. org/10.1029/2005WR004155.

Nobre, A. D., Cuartas, L. A., Hodnett, M., Rennó, C. D., Rodrigues, G., Silveira, A., Waterloo, M., \& Saleska, S. (2011). Height above the nearest drainage-a hydrologically relevant new terrain model. 
Journal of Hydrology, 404(1-2), 13-29. http://dx.doi.org/10.1016/j. jhydrol.2011.03.051.

Oliveira, G. A., Cirilo, J. A., Brito, P. L., \& Elias, E. N. N. (2019). Qualidade do posicionamento em aplicativos VGI obtido por sensores de localização em smartphones. Revista Brasileira de Cartografia, 71(3), 806-831. http://dx.doi.org/10.14393/rbcv71n3-49478.

Oliveira, G. A., Cirilo, J. A., \& Ribeiro, A. A. S. (2018). Desenvolvimento de plataforma colaborativa para registro de inundações na escala intraurbana. In: 12. Encontro Nacional de Águas Urbanas. Maceió, AL: ABRH.

Oliveira, R. L. M., \& Silva, S. R. (2016). Estudos de eventos extremos de chuva na bacia hidrográfica do Rio Una. Revista de Engenharia e Pesquisa Aplicada, 2(1), 156-160. http://dx.doi.org/10.25286/repa.v2i1.317.

Pereira, M. L. T., Soares, M. P. A., Silva, E. A., Montenegro, A. A. A., \& Souza, W. M. (2017). Variabilidade climática no Agreste de Pernambuco e os desastres decorrentes dos extremos climáticos. Journal of Environmental Analysis and Progress, 2(4), 394-402. http:/ / dx.doi.org/10.24221/jeap.2.4.2017.1452.394-402.

Pinheiro, V. B., Naghettini, M., \& Palmier, L. R. (2019). Uncertainty estimation in hydrodynamic modeling using Bayesian techniques. Brazilian Journal of Water Resources, 24(38), e38. http://dx.doi. org/10.1590/2318-0331.241920180110.

Poser, K., \& Dransch, D. (2010). Volunteered geographic information for disaster management with application to rapid flood damage estimation. Geomatica, 64(1), 89-98.

Ribeiro Neto, A., Cirilo, J. A., Dantas, C. E. O., \& Silva, E. R. (2015). Caracterização da formação de cheias na bacia do rio una em Pernambuco: simulação hidrológica-hidrodinâmica. Revista Brasileira de Recursos Hidricos, 20(2), 394-403. http:/ / dx.doi. org/10.21168/rbrh.v20n2.p394-403.

Rollason, E., Bracken, L. J., Hardy, R. J., \& Large, A. R. G. (2018). The importance of volunteered geographic information for the validation of flood inundation models. Journal of Hydrology (Amsterdam), 562, 267-280. http://dx.doi.org/10.1016/j.jhydrol.2018.05.002.

Samela, C., Albano, R., Sole, A., \& Manfreda, S. (2018). A GIS tool for cost-effective delineation of flood-prone areas. Computers, Environment and Urban Systems, 70, 43-52. http://dx.doi.org/10.1016/j. compenvurbsys.2018.01.013.

Scorzini, A. R., Radice, A., \& Molinari, D. (2018). A New Tool to Estimate Inundation Depths by Spatial Interpolation (RAPIDE): Design, Application and Impact on Quantitative Assessment of Flood Damages. Water (Basel), 10(12), 1805. http://dx.doi. org/10.3390/w10121805.

Seibert, J., Strobl, B., Etter, S., Hummer, P., \& Meerveld, H. J. (2019). Virtual staff gauges for crowd-based stream level observations. Frontiers of Earth Science, 7(70)
Shidawara, M. (1999). Flood hazard map distribution. Urban Water, 1(2), 125-129. http://dx.doi.org/10.1016/S1462-0758(00)00002-9.

Teng, J., Jakeman, A. J., Vaze, J., Croke, B. F. W., Dutta, D., \& Kim, S. (2017). Flood inundation modelling: a review of methods, recent advances and uncertainty analysis. Environmental Modelling \& Software, 90, 201-216. http://dx.doi.org/10.1016/j.envsoft.2017.01.006.

Tucci, C. E. M. Inundações Urbanas. Porto Alegre: ABRH/RHAMA, 2007.

Universidade Federal de Santa Catarina - UFSC. (2016). Relatório de danos materiais eprejuizos decorrentes de desastres naturais no Brasil: 1995 - 2014. Florianópolis, SC: Universidade Federal de Santa Catarina.

United States Army Corps of Engineers. Hydrologic Engineering Center. (2016). HEC-RAS: User's Manual, version 5.0. Davis, CA: USACE-HEC.

Wing, O. E. J., Bates, P. D., Sampson, C. C., Smith, A. M., Johnson, K. A., \& Erickson, T. A. (2017). Validation of a 30 $\mathrm{m}$ resolution flood hazard model of the conterminous United States. Water Resources Research, 53(9), 7968-7986. http://dx.doi. org/10.1002/2017WR020917.

Wood, M., Hostache, R., Neal, J. C., Wagener, T., Giustarini, L., Chini, M., Corato, G., Matgen, P., \& Bates, P. D. (2016). Calibration of channel depth and friction parameters in the LISFLOOD-FP hydraulic model using medium-resolution SAR data and identifiability techniques. Hydrology and Earth System Sciences, 20(12), 4983-4997. http://dx.doi.org/10.5194/hess-20-4983-2016.

\section{Authors contributions}

Ayane Aparecida da Silva Ribeiro: Study conception, literature review, field data collection, the empirical model structuring, data analysis, writing and proofreading.

Gabriel Araujo de Oliveira: Literature review, the empirical model and the hydrodynamic model structuring, data analysis, writing and proofreading.

José Almir Cirilo: Guidance and supervision of work, data analysis, writing and proofreading.

Fellipe Henrique Borba Alves: The hydrodynamic model structuring, data analysis, writing and proofreading.

Larissa Ferreira David Romão Batista: Literature review; data analysis; text revision; manuscript translation.

Vitor Barbosa Melo: Literature review; data analysis, writing and proofreading. 